\title{
Bladder Wall
}

National Cancer Institute

\section{Source}

National Cancer Institute. Bladder Wall. NCI Thesaurus. Code C48941.

The tissue layers that form the urinary bladder. They include the mucosa, submucosa, smooth muscle, and serosa. 